\title{
A MACRO GRAIN SIZE TECHNIQUE FOR URANIUM
}

\author{
BY \\ H. R. GARDNER \\ PILE TECHNOLOGY SECTION \\ ENGINEERING DEPARTMENT
}

FEBRUARY 9, 1956

HANFORD ATOMIC PRODUCTS OPERATION

RICHLAND, WASHINGTON

GENERAL ELECTRIC 


\section{DISCLAIMER}

This report was prepared as an account of work sponsored by an agency of the United States Government. Neither the United States Government nor any agency Thereof, nor any of their employees, makes any warranty, express or implied, or assumes any legal liability or responsibility for the accuracy, completeness, or usefulness of any information, apparatus, product, or process disclosed, or represents that its use would not infringe privately owned rights. Reference herein to any specific commercial product, process, or service by trade name, trademark, manufacturer, or otherwise does not necessarily constitute or imply its endorsement, recommendation, or favoring by the United States Government or any agency thereof. The views and opinions of authors expressed herein do not necessarily state or reflect those of the United States Government or any agency thereof. 


\section{DISCLAIMER}

Portions of this document may be illegible in electronic image products. Images are produced from the best available original document. 
UNCLASSIFIED

Declassified by authority of

H. F. Carroll

Declassification Branch, Oak Ridge

$$
\frac{\mathrm{HW}-41343}{\begin{array}{c}
\text { Metallurgy and Ceramics } \\
\text { (TID-4500, 1lth Ed.) }
\end{array}}
$$

July 17, 1956

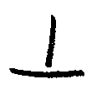

A MACRO GRAIN SIZE TECHNIQUE FOR URANIUM

By

H. R. Gardner

Fuel Element Development Unit

Fuel Technology Sub-Section

February 9, 1956

\section{HANFORD ATOMIC PRODUCTS OPERATION RICHLAND, WASHINGTON}

Work performed under Contract No. W-31-109-Eng-52 between the Atomic Energy Commission and General Electric Company

Printed by/for the U. S. Atomic Energy Commission 


\section{INTERNAL DISTRIBUTION}

Copy Number

$\begin{aligned} 1 & \text { F. W. Albaugh } \\ 2 & \text { J. A. Ayres } \\ 3 & \text { J. A. Berberet } \\ 4 & \text { W. A. Blanton } \\ 5 & \text { L. P. Bupp } \\ 6 & \text { S. H. Bush } \\ 7 & \text { J. J. Cadwell } \\ 8 & \text { V. R. Cooper } \\ 9 & \text { J. M. Fox } \\ 10 & \text { J. M. Fouts } \\ 11 & \text { R. M. Fryar } \\ 12 & \text { H. R. Gardner } \\ 13 & \text { S. M. Gill } \\ 14 & \text { O. H. Greager } \\ 15 & \text { G. B. Hansen-P. R. Anderson } \\ 16 & \text { L. A. Hartcorn } \\ 17 & \text { W. T. Kattner-O. W. Rathbun } \\ 18 & \text { L. W. Lang } \\ 19 & \text { W. K. MacCready } \\ 20 & \text { W. M. Mathis } \\ 21 & \text { J. F. Music } \\ 22 & \text { C. A. Priode } \\ 23 & \text { P. H. Reinker } \\ 24 & \text { R. B. Richards } \\ 25 & \text { J. W. Riches } \\ 26 & \text { K. V. Stave } \\ 27 & \text { J. T. Stringer } \\ 28 & \text { M. A. Tupper } \\ 29 & \text { F. W. Van Wormer } \\ 30 & \text { W. P. Wallace } \\ 31 & \text { W. W. Windsheimer } \\ 32 & \text { E. C. Wood } \\ 33 & \text { Yellow File } \\ 34 & \text { 300 Files } \\ & \end{aligned}$




\begin{abstract}
$\underline{\text { ABSTRACT }}$
A macro grain size technique was developed for estimation of the grain size of beta heat treated uranium. The macroetched sample is viewed through a modified Bausch and Lomb 'Eyepiece for Grain Size Deter mination" at a magnification of 20 under bright field illumination. Eight replicas of the ASTM grain size grids, ranging from 0.2 to $0.9 \mathrm{~mm}$ average grain diameter were constructed and inserted in the rotating reticle of the eyepiece. A $20 \mathrm{X}$ grain size chart and a series of $20 \mathrm{X}$ grain size overlays were constructed. A more reproducible and meaningful estimate of grain size is obtained by this technique than the existing micro $(100 X)$ technique.
\end{abstract}




\section{A MACRO GRAIN SIZE TECHNIQUE FOR URANIUM}

\section{INTRODUCTION}

The grain structure of uranium has been studied by two methods; a micro technique (1) and a macro technique (2). Both techniques have proven useful in the study of the grain structure of uranium. The micro technique enables a detailed examination of the electropolished sample. under polarized light at 100X, for subgraining, twinning, and possibly micro-cracking. The macro technique, which utilizes a much simpler sample preparation procedure (2) and bright field illumination at magnifications from 1 to $30 \mathrm{X}$, allows a quick evaluation of changes in size, shape, and degree of twinning of the macro grains.

Determination of the micro grain size of both high alpha rolled uranium and "recrystallized" beta-quenched uranium (Figure $2 \mathrm{~b}$ ) produces a satisfactory result because of their equiaxed structures. However, when this technique is applied to the sub grained microstructure of beta phase heat-treated uranium a number of difficulties arise. During metallographic examination under polarized illumination, (4) a slight rotation of the metallograph stage results in the appearance of a large number of new grains or sub-grains (Figure 1). This, plus the large size of the beta transformed alpha grains increases the difficulty of obtaining a reproducible micro grain size estimate.

(1) Appendix 1.

(2) Appendix 2 .

(3) Gardner, H. R., HW-34368, Jan. 3, 1955.

(4) At the present time a useable microtechnique for the bright field examination of the grain structure of uranium has not been developed. 
Because of these inadequacies of the micro-technique it was thought that a macro-technique, where the macro-etched sample is viewed under bright field illumination at a low magnification in the range from 5 to $30 \mathrm{X}$, would aid in obtaining a useful and reproducible uranium grain size estimate.

\section{OBJECTIVE}

The objective of this experiment was to develop a grain size technique for beta transformed uranium that will result in a reproducible and meaningful grain size estimate.

SUMMARY

A macro grain size technique was developed wherein the macro etched sample is examined through a modified Bausch and Lomb "Eyepiece for Grain Size Determination" under bright field illumination at a magnification of 20. The Bausch and Lomb eyepiece was modified to include 8 replicas of the ASTM grain size grids ranging in average grain diameter from 0.2 to $0.9 \mathrm{~mm}$. A $20 \mathrm{X}$ grain size chart and a series of $20 \mathrm{X}$ grain size overlays were also developed during the course of this work.

$\underline{\text { DISCUSSION }}$

A series of macroetched uranium samples with a range of gra in sizes were viewed through a Bausch and Lomb Model AKW-5 stereomicroscope at magnifications of 10 and 20. Grain sizes were estimated at these magnifications by comparison with an ASTM grain size chart (6). The ASTM numbers obtained from the charts (which were for $100 \mathrm{X}$ comparison) were converted to use at $20 \mathrm{X}$ by assuming a spherical grain

(6) "Metals Handbook", American Society for Metals, 1948 Edition, Taylor Lyman, pages 401 to 403 . 
and calculating average grain diameter (7) from the average values for grains $/ \mathrm{mm}^{2}$ given in the "Metals Handbook" (6). The average grain diameter obtained, on the samples tested, ranged from 0.2 to $0.9 \mathrm{~mm}$, From this preliminary work, it was decided that estimation of the grain size of uranium macrostructures at $20 \mathrm{X}$ (Figure $2 \mathrm{a}$ ) would give a satisfactory result. Consequently, a 20X macro grain size chart (Figure 3) was prepared for use in estimating grain size.

While applying this technique it was found that the precision for a single observer was excellent, however, the precision between several different observers was not as favorable. In an attempt to improve the precision between observers, a Bausch and Lomb "'Eyepiece for Grain Size Determination" was modified (8) to contain 8 grain size grids permitting the estimation of grain sizes from 0.2 to $0.9 \mathrm{~mm}$ average grain diameter at a magnification of 20 (Figure 4).

During the initial application of the modified eyepiece, it was found that the precision of estimation between observers could be greatly improved by making two grain size estimates on a sample; one estimate was made for the large grains of a similar size occupying the major portion of the sample and the other for the much smaller grains which occupy very little of the sample area.

\section{CONCLUSIONS}

The $20 \mathrm{X}$ macrotechnique developed for the estimation of the macro-grain size of uranium is considered adequate. The precision of estimation between observers is very good. Advantages of the macrotechnique over the microtechnique include:

(a) Grain size estimates made with the macro technique,

(1) have a more important relationship to the in-pile characteristics of uranium.

(2) correlate satisfactorily to the visual appearance of the macrostructure.

(7) Appendix 3 .

(8) Appendix 4. 
(b) A quicker and more economical sample preparation procedure, no polishing other than 120 grit wet belt grinding is necessary.

(c) A simple macroscope and bright field illumination are used instead of a metallograph and polarized illumination.

\section{ACKNOWLEDGEMENT}

The writer wishes to express his appreciation to J. M. Holeman of the Optical Shop, J. L. Hascall of the Photography Unit, L. A. Harticorn of the Metallographic Laboratory and the people of the Technical Draft:ng Unit for their cooperation and outstanding work on the various phases of this project.

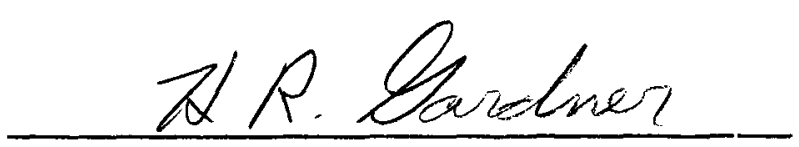

H. R. Gardner

HRG:dt 


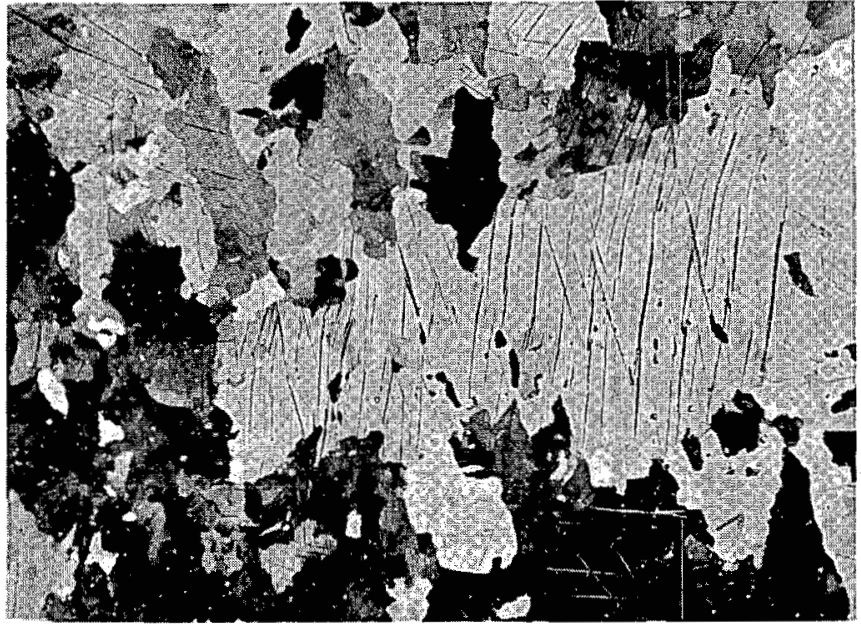

$0^{\cup}$ Stage Rotation

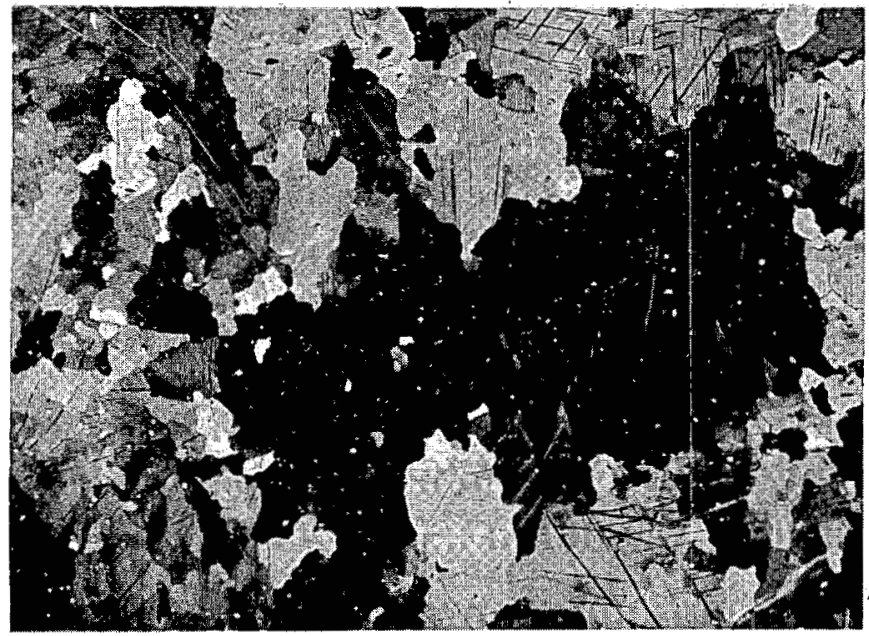

$204^{\circ}$ Stage Rotation

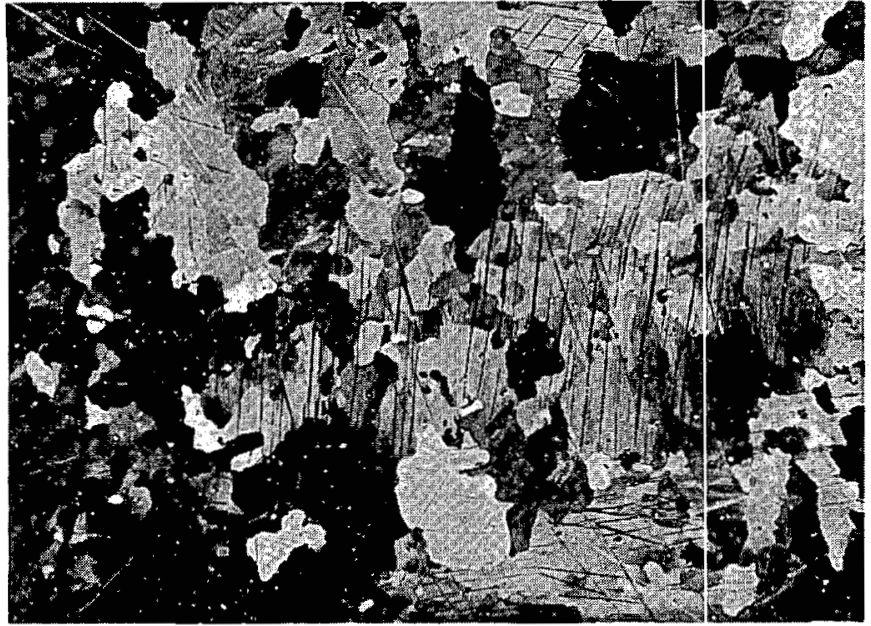

$106^{\circ}$ Stage Rotation

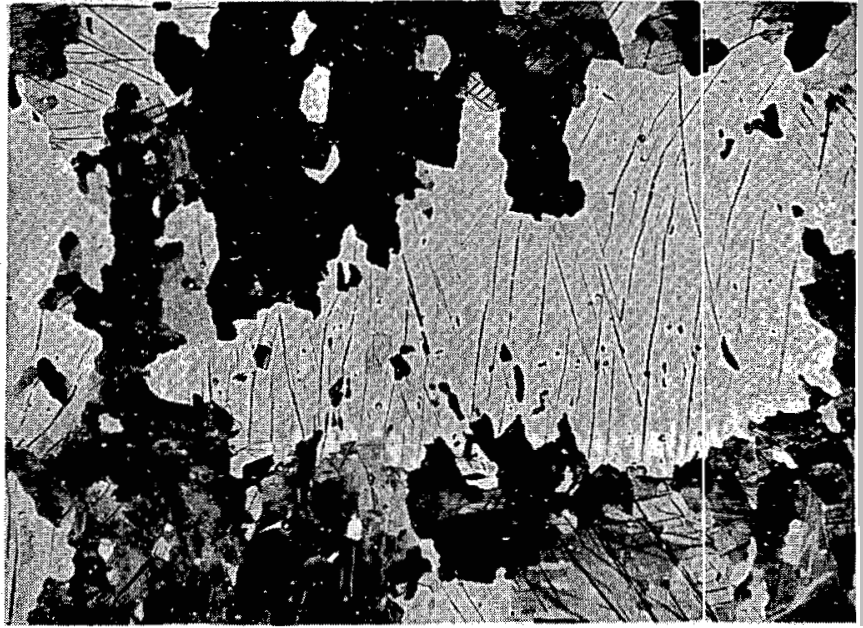

$267^{\circ}$ Stage Rotation

\section{FIGURE 1}

The photomicrographs (50X) illustrate the change in appearance of a selected area viewed under polarized illumination, as the metallograph stage is rotated through 360 degrees. The orientation of the uranium sample to the film was maintained constant in each case. Final sample preparation consisted of an electropolish in a solution of phosphoric acid, ethylene glycol and ethyl alcohol. 


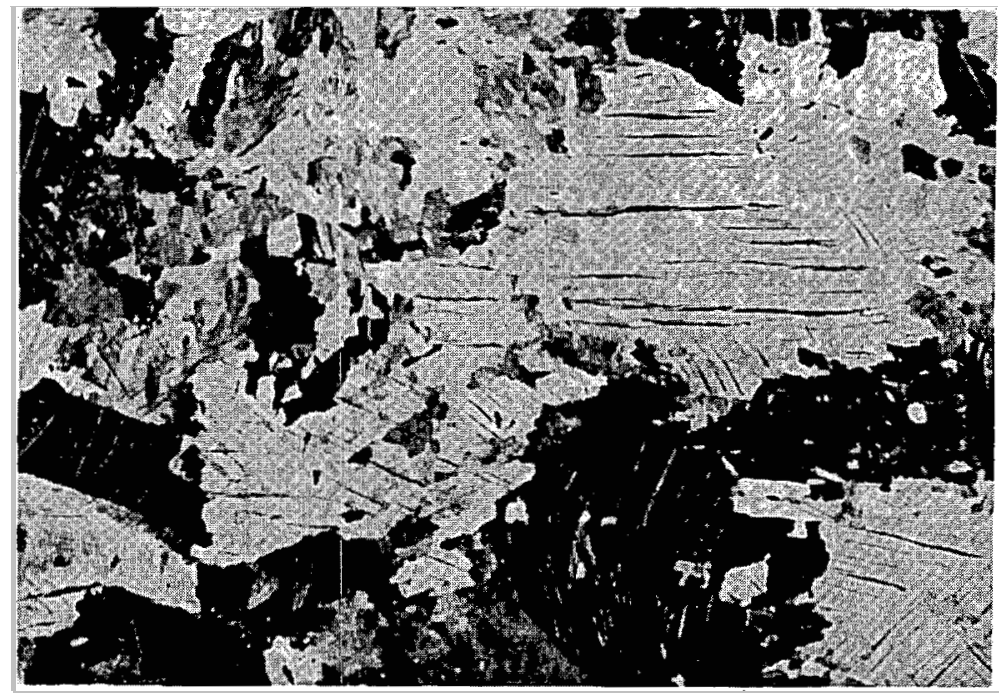

FIGURE 2a

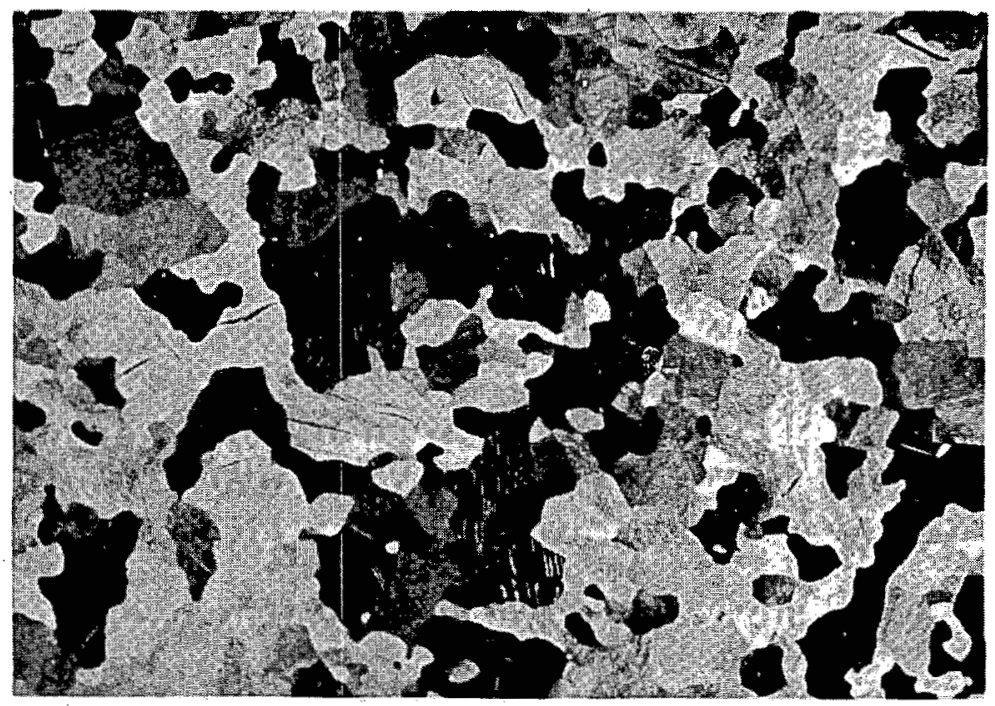

FIGURE 2b

Photomacrographs (20X) of transverse uranium sections; beta quenched (2a) and beta quenched, recrystallized (2b). Samples macroetched in separate solutions of concentrated hydrochloric and nitric acid. 


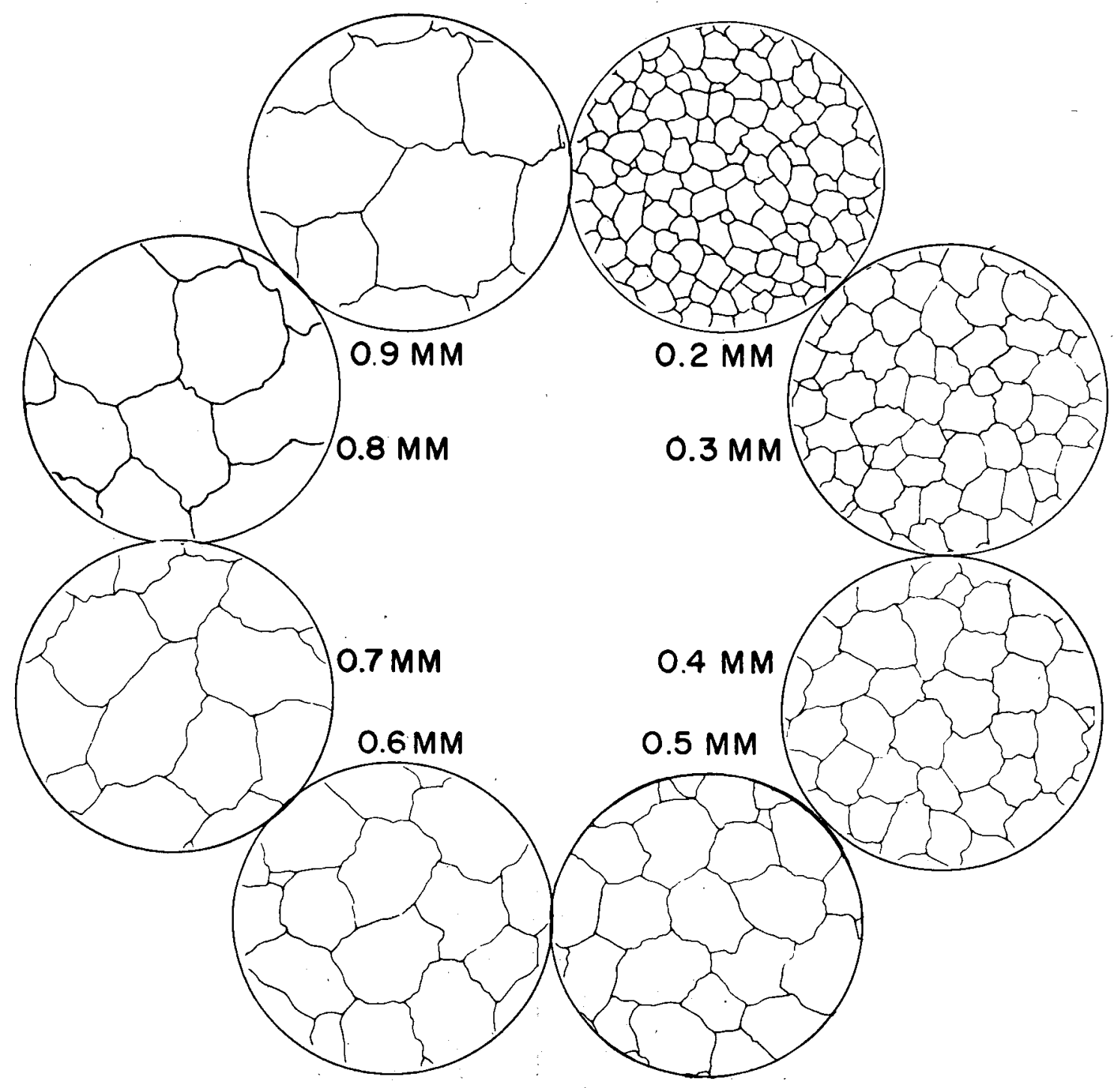

F IGURE 3

Grain Size Chart for 20X Macro Comparison 

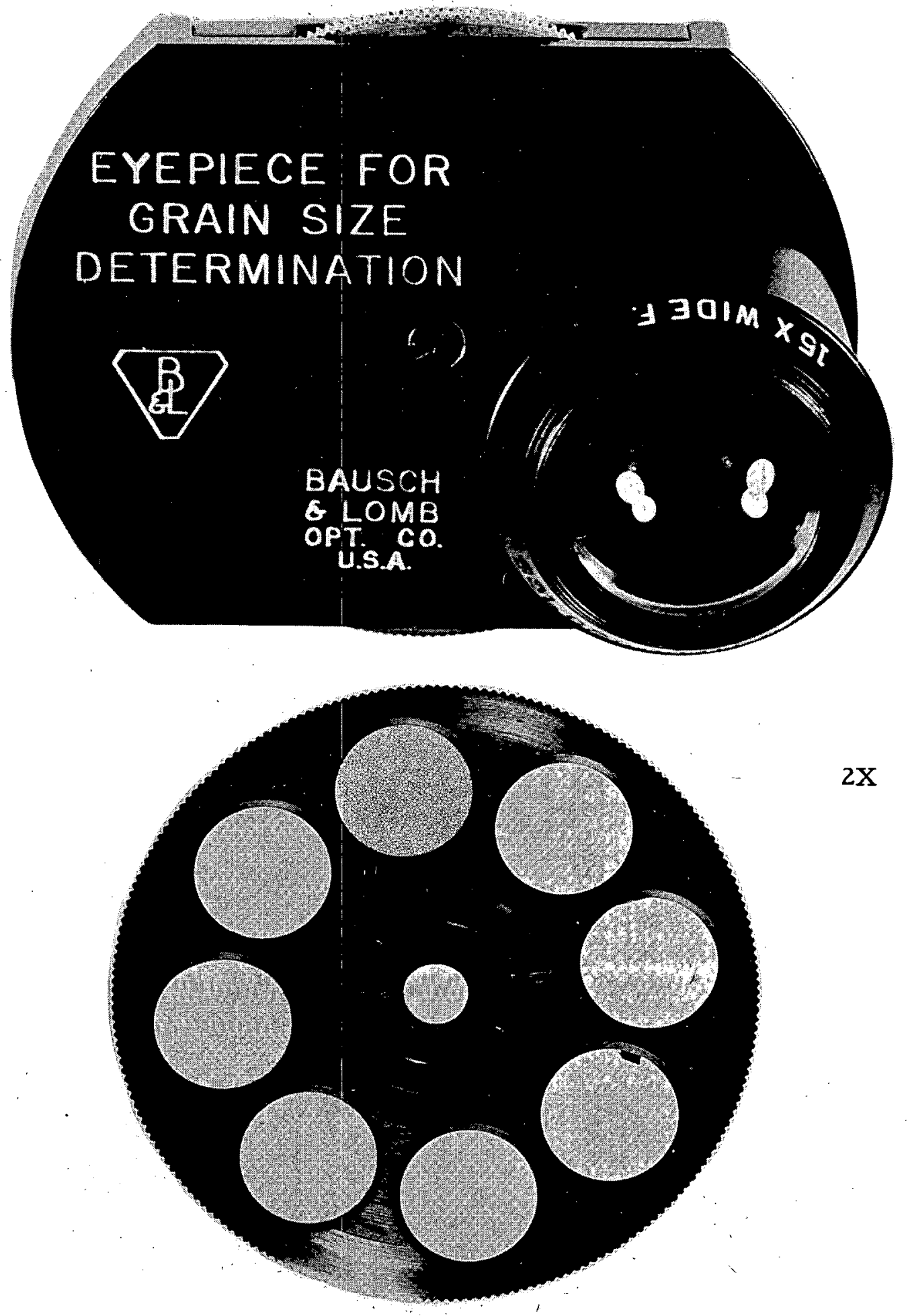

F IGURE 4

Bausch and Lomb "Eyepiece for Grain Size Determination", and metal disk containing grid inserts for grain size determination at $20 \mathrm{X}$. 


\section{APPENDIX I}

SAMPLE PREPARATION FOR MICRO TECHNIQUE

After mounting the sample in bakelite the following hand grinding technique is used for the initial sample preparation:

(a) Grind on a wet belt sander on the 80 and 240 grit belts.

(b) Proceed on emery cloths through the $3 / 0$ cloth using a solution of $5 \%$ paraffin in kerosene as a lubricant.

Final sample preparation consists of a 3 to 5 minute electropolish in a solution of 5 parts phosphoric acid, 5 parts ethylene glycol and 8 parts ethyl alcohol at a current density of 30 milliamps per square centimeter and 18 to 20 volts D. C.

\section{APPENDIX II}

\section{SAMPLE PREPARATION FOR MACRO TECHNIQUE}

The surface of the unmounted sample is prepared by grinding on a 120 grit wet belt sander. The macroetch used involves immersion of: the sample in a concentrated hydrochloric acid solution for 30 to 45 seconds followed by a water rinse. A two second dip in a concentrated nitric acid solution followed by a water rinse completes the etching sequence and produces a well defined macro grain structure.

\section{APPENDIX III}

\section{CALCULATIONS FOR GRAIN SIZE CHART}

The following table contains the calculations of the average grain diameter at $20 \mathrm{X}$ and $100 \mathrm{X}$ from the grains $/ \mathrm{mm}^{2}$ values (9) used to estimate grain sizes at 20X. A series of samples with an extreme range of grain sizes were used for grain size estimation. The grain sizes obtained at $20 \mathrm{X}$ by comparison with the ASTM chart fell between 0.2 and $0.9 \mathrm{~mm}$ (9) "Metals Handbook," American Society for Metals, 1948 Edition, Taylor Lyman, pp, 401-403. 
average grain diameter. Therefore a grain size chart was established for this range of average grain diameter.

$100 \mathrm{X}$

ASTM No. Grains $/ \mathrm{mm}^{2} \quad \underline{\begin{array}{c}\text { Average Grain } \\ \text { Diameter }(\mathrm{mm})(1)\end{array}}$

$\begin{array}{rr}1 & 16 \\ 2 & 32 \\ 3 & 64 \\ 4 & 128 \\ 5 & 256 \\ 6 & 512 \\ 7 & 1024 \\ 8 & 2048\end{array}$

$0: 242$

0.199

0.141

0.100

0.070

0.050

0.033

0.025
$20 \mathrm{X}$

Average Grain Diameter $(\mathrm{mm})(2)$

(1) Average grain diameter was obtained by assuming a spherical grain and calculating the diameter of a grain from the number of grains $/ \mathrm{mm}^{2}$.

(2) The $20 \mathrm{X}$ values were obtained by multiplying the $100 \mathrm{X}$ average grain diameter by the factor $100 / 20$ or 5 .

\section{APPENDIX IV}

\section{MODIFICATION OF GRAIN SIZE EYEPIECE}

Grid Inserts

The Bausch and Lomb "Eyepiece for Grain Size Determination" originally had 8 different grids on a rotating stage, each grid consisting of a network of a particular size square. This type of grid proved to be inadequate for grain size estimation of uranium at 20X. However, it was felt that a grid of the type appearing in the ASTM Standards ${ }^{(1)}$ would be satisfactory.

Using the No, 6 ASTM grain size grid as a base, a series of 8 grids of different grain sizes were constructed by tracing with a pantograph.

(1) ASTM Standards, 1952, Part 1, Ferrous Metals ${ }^{\text {F }}$ p. 1436. 
After photographically reducing the tracings to the proper size the grids were printed on spectrographic glass. A circular area bearing a particular grid was cut from the glass and mounted in the eyepiece. Similarly the other seven grid sizes were cut and mounted. In addition, using a different reduction in magnification of the tracings the 20X grain size chart and overlays were prepared.

Table I contains a summary of the data developed for use in the construction of the eyepiece grid inserts, and grain size chart and overlays. The values in the table are based on a field of view in the eyepiece of $0.400 "$ and an average grain diameter of $5.1 \mathrm{~mm}$ for ASTM grid No. 6 at $1 \mathrm{X}$. 
TABLE I

CALCULATIONS FOR GRAIN SIZE GRIDS ON GLASS INSERTS

IN GRAIN SIZE EYEPIECE AND ON GRAIN SIZE CHART

\begin{tabular}{|c|c|c|c|c|c|c|}
\hline \multirow[b]{2}{*}{$\begin{array}{l}\text { Req. Avg. } \\
\text { Grain Diam. } \\
\text { at } 1 X \\
(\mathrm{~mm})\end{array}$} & \multirow[b]{2}{*}{$\begin{array}{l}\text { Avg. Grain } \\
\text { Diam. as } \\
\text { Traced by } \\
\text { Pantograph } \\
\text { (1) }(\mathrm{mm}) \\
\end{array}$} & \multirow[b]{2}{*}{$\begin{array}{l}\text { Avg. Grain } \\
\text { Diam. on } \\
\text { Glass Insert } \\
(2)(\mathrm{mm}) \\
\end{array}$} & \multirow[b]{2}{*}{$\begin{array}{l}\text { Avg. } \\
\text { Grain } \\
\text { Diam. } \\
\text { at } \\
20 X(\mathrm{~mm}) \\
\end{array}$} & \multicolumn{3}{|c|}{$\begin{array}{l}\text { Length of base (3) } \\
\text { line (inches) }\end{array}$} \\
\hline & & & & Tracing & $\begin{array}{l}\text { Glass } \\
\text { Insert }\end{array}$ & $\begin{array}{l}\text { cox } \\
\text { Grain } \\
\text { Size } \\
\text { C'hart }\end{array}$ \\
\hline 0.2 & 10.20 & 0.27 & 4 & 4 & 0.21 & 3.14 \\
\hline 0 . & & & 6 & 4 & & \\
\hline U. & & & 8 & 4 & & 6.28 \\
\hline 0 。 & & 0 & 10 & 2 & 0 . & 3.92 \\
\hline 0. & & & 12 & 2 & & 4.70 \\
\hline 0 . & & 0 & 14 & 2 & 0.37 & 5.49 \\
\hline 0. & & & 16 & 2 & 0.42 & 6.2 \\
\hline 0.9 & 45.90 & 1.20 & 18 & 2 & 0.47 & 7.05 \\
\hline
\end{tabular}

(1) The reason for the pantograph tracings was to produce a series of grain size grids with a constant grain boundary width. The tracings were then reduced by factors of 38.35 and 25.5 for the glass inserts on on the eyepiece, and the grain size chart and overlays respectively. Straight photographic enlargement would produce grids with grain boundary widths that undesirably increased with increasing grain size.

(2) For example, the average grain diameter $0.2 \mathrm{~mm}$ becomes $4.0 \mathrm{~mm}$ when viewed at $20 \mathrm{X}$. Using an eyepiece magnification of $15 \mathrm{X}$, the average grain diameter necessary on the glass insert is obtained from the ratio $4 / 15$ or $0.27 \mathrm{~mm}$.

(3) On each of the pantograph tracings a base line of known length was drawn to aid in obtaining the proper magnification for the grids on the glass inserts and on the grain size chart and overlays. 


\section{Magnification}

On the Bausch and Lomb AKW-5 stereo-microscope a sample magniciation of 20 is obtained by using a $15 \mathrm{X}$ eyepiece in combination with a 1. 3X objective. When the Bausch and Lomb "Eyepiece for Grain Size Determination"' is used on the AKW-5 the optical tube length is increased from $160 \mathrm{~mm}$ to $175 \mathrm{~mm}$, thereby increasing the magnification of the objective to 1.4. The original eyepiece lens in the ${ }^{8}$ Eyepiece for Grain Size Determination" had a magnification of 10.8. Using this lens in combination with the new objective magnification of 1.4 resulted in a sample magnification of 15.1. To approximate 20X, a $15 \mathrm{X}$ lens was substituted in the grain size eyepiece resulting in a sample magnification of 21.0. For most grain size estimation the slight correction $\left(\frac{20}{21}\right)$ can be neglected. 